Karolina Kmiecik-Jusięga ${ }^{1}$ iD http:/orcid. org/0000-0002-2483-3619

Jesuit University Ignatianum in Cracow

\title{
SZPAKOWISKO. A STORY ABOUT A YOUTH MOVEMENT SUPPORTING THE BUILDING OF A GROUP IDENTITY OF (SELF)EXCLUDED PEOPLE
}

Su m m a r y: The aim of the article is to present a little-known social phenomenon created by young people who from the 1980 s to the first decade of the $21^{\text {st }}$ century participated in Szpakowiska, i.e. cyclical meetings supervised by Fr Andrzej Szpak, Salesian (1944-2017). The factors specific to Szpakowisko will be highlighted, which contributed to the socialisation of people who were originally excluded or self-excluded from social structures. The author attempts to answer the questions: What was the character of the youth movement called Szpakowisko? Which elements of this movement can be described as factors that build group identity? The introduction presents the research method and dilemmas related to the topic of the article. Next, Szpakowisko is characterised as a support group, the identity-building process is discussed, and selected elements of the phenomenon are highlighted, such as a common communication code, search, mentality and self-exclusion community.

Ke yw ord s: Szpakowisko, youth movement, group identity, self-exclusion

\section{Introduction}

By providing the material for interpretation of important personal meaning, identity building from the lives of individuals, the idiographic ${ }^{2}$ studies become $^{2}$ a vital need of our time $e^{3}$. This is particularly true for the contemporary world of

1 Dr Karolina Kmiecik-Jusięga, Institute of Educational Sciences, Jesuit University Ignatianum in Cracow, ul. Kopernika 26, 31-501 Kraków; e-mail: karolina.kmiecik-jusiega@ignatianum.edu.pl.

2 Greek ídios own, private, individual, gráphō I write.

3 Carlo Nanni, "Personalistyczny wymiar filozofii wychowania". In: Personalistyczny wymiar wychowania, eds. Anna Szudry, Katarzyna Uzar (Lublin: Wydawnictwo KUL, 2009), 69. 
young people which is atomising at a radical and geometrical progression, forming iconographic fragmentations, floating in virtual space, far beyond the social reality. It seems that in the second decade of the $21^{\text {st }}$ century, the young internet generation of people do not need meetings, rallies, gatherings, small cultures, direct interpersonal relations, not to mention counterculture groups which were a part of the youth history in the previous century. They were an object of interest for resocialisation pedagogues also in literature, and now are the stories told by forty-year-old or elder witnesses of events which - from today's perspective can be called youth movements, certain social phenomena occurring in the space unattainable to scholars who are not personally involved. Generally, from the perspective of scientific cognition, distancing from the described phenomenon would probably generate schematisations, generalisations and descriptions disturbing the true picture and having little to do with what really was happening. On the other hand, a lack of distance or a small distance can make a scholar emotional and biased, limiting the objective description.

Despite these deficiencies and imperfections of the research procedure, the author decided to use the narrative method which is a form of an individual's account about the entire life or a specific part of it which is important from a perspective of development, because using the criterion of described area, the narrative can be divided into a complete or thematic one (fragmentary) ${ }^{4}$. As Mirosława Nowak-Dziemianowicz puts it, the narrative is understood not only as biographical story about ' $\mathrm{I}$ ', it is also presented as our way of being in the world, the way in which we obtain the unity of our existence ${ }^{5}$. In one of Susan E. Chase's perspectives, the discussed method can be understood as something that exists only as a result of specific social circumstances, as it contains an image of a certain social reality ${ }^{6}$.

In the case of a short, fragmentary story presented in this article, the method is a verbal one, albeit supported by documentation, reconstruction of certain events that took place in the 1990s, created by a group of youths and young adults around the open, non-institutionalised, pastoral-pedagogical activity of Fr Andrzej Szpak ${ }^{7}$, in the perspective of social (self)exclusion, and simultaneously attempting to build the identity of a person belonging to a social movement. The

4 Danuta Urbaniak-Zając, Ewa Kos, Badania jakościowe w pedagogice. Wywiad narracyjny i obiektywna hermeneutyka (Warszawa: PWN, 2013), 96.

5 Mirosława Nowak-Dziemianowicz, Walka o uznanie $w$ narracjach. Jednostka $i$ wspólnota w procesie poszukiwania tożsamości (Wrocław: DSW, 2016), 11.

6 Urbaniak-Zając, Kos, Badania..., 97.

7 See Karolina Kmiecik-Jusięga, Szpaku. Metody pracy księdza Andrzeja Szpaka z młodzieża różnych dróg (Kraków: WAM, 2013); Andrzej Szpak SDB, Idź Mojżeszu. O pielgrzymce, hipisach i ziemi obiecanej (Kraków: ESPE, 2015); idem, "Wychowanie religijne w ruchu hipisów i młodzieży różnych dróg. 40-letnie poszukiwania i doświadczenia duszpasterskie”. In: Hipisi, wędrowcy marzeń i poszukiwacze wolności na ścieżkach wspótczesnej kultury, eds. Gerard Guźlak, Anna Pietrzak (Bydgoszcz: UKW, 2016). 
mechanisms, phenomena and facts described and interpreted below are reconstructed fragments of reality in which the author participated.

From the 1980s to the early $21^{\text {st }}$ century, Szpakowisko was a unique ideal of pastoral-pedagogical work with young social misfits in the broad sense of the term. Similarly to dissenting rallies of Polish hippies ${ }^{8}$, the Salesian Andrzej Szpak formed a community of people who shared a similar vision of reality, problems and outlook on life. As it was impossible to act in an institutionalised framework ${ }^{9}$, Fr Andrzej Szpak provided the space to meet, co-be, talk, make friends, and such friendships were often stronger than those formed at school or in other social groups. Szpakowisko was a place and time in which one important adult was always PRESENT, thus embodying the Salesian Assistance necessary in the education process.

\section{Participants of Szpakowisko - Spiritually Lost Youth ${ }^{10}$}

The vast majority of young people (mainly teenagers and young adults) with whom Fr Szpak worked were desperately seeking support from other men and women with unfulfilled needs of affiliation, physical closeness, respect and recognition, but also hurt, feeling lonely, rejected and alienated, with extreme individualism in their family and peer environment ${ }^{11}$. Very often, the searches in combination with the feeling of exclusion (particularly in the family) led to experimenting with psychoactive substances, for many resulting in addiction or diseases and mental disorders. In such a difficult, open, non-institutionalised environment, the use of any secular method would soon cause a professional burnout or a need to cooperate with supervisors whom Fr Szpak did not have. His strength was a great faith in God thanks to which he developed his pedagogical and psychological abilities and could cope with cases with which the secular experts were helpless.

Fr Andrzej claimed that the youth who seek drugs, alcohol and casual relationships are spiritually unformed, lost and non-integrated, and consequently deprived of the sense of security and internal stabilisation. They are also not adapted for the society that lives on the run, is extrovert, and oriented towards material profits and professional careers. Therefore, they need not only training in how to find themselves in the material world, but most of all evangelisation

8 Kmiecik-Jusięga, Szpaku..., 202-208.

9 See extended interview with Fr Andrzej Szpak by Gabriela Mruszczak, Filmoteka Małopolska, produced by RAMstudio Company S.C., https://www.youtube.com/watch?v=gJs2bjc08To (access: 28.01.2020).

10 Reconstructed fragment of the author's article: "Ksiądz Andrzej Szpak SDB - duszpasterz niedostosowanych", Remedium 2 (2013).

11 See Andrzej Szpak SDB, "Wychowanie religijne...." 
in the spirit of the "Christian method of liberation, conversion and personal development in the form of Mystery of Love, Word and Grace"12. However to conduct such evangelisation, you need to establish and maintain relations with people who in many cases never had positive relations with others, even with their parents. That is why trust, full honesty and love - understood as caritas - are so important.

Coming to Szpakowisko taking part in the mass whose form differs from traditional masses in the church, listening to Fr Szpak, the youth began to discover the truth about themselves, their families and God. They attained a sort of enlightenment and often came home with different views and attitudes towards the world. However, this did not happen after only one meeting; sometimes it took somebody years to discover the truth, and Fr Szpak helped in that. He convinced the most unconvinced. He searched for such arguments and such forms of expression that most secular as well as clerical educators do not use. He mainly relied on experiences, live examples, and the testimonies of people who kicked the habit and found the sense of life in family and their local community. He listened, remembered names and behaved as if the person he spoke to was the most important in the whole world.

\section{Szpakowisko as a Support Group}

Szpakowisko were youth meetings ${ }^{13}$ organised from the turn of the 1970s and 1980s by Fr Andrzej Szpak, a Polish Salesian (28.01.1944-18.11.2017). Until the early $21^{\text {st }}$ century, they became rather systematic ecumenical and also pedagogical-psychological meetings which had a cultural and religious overtone and took place in specified locations at specified dates. Initially, this was even once a month in various Polish cities, also in combination with music festivals such as Rawa Blues in Katowice, Music Camping in Brodnica, or Jarocin Rock Festival. Later, Szpakowisko took place a few times a year, and in the first decade of $21^{\text {st }}$ century on Divine Mercy Sunday in Kraków, around Saint Andrew's Day in Częstochowa and during Christmas, most often in Kraków. At that time pilgrimages led by Fr Szpak until 2017 were also called Szpakowisko ${ }^{14}$. It has its foundations because a pilgrimage is a social phenomenon, an event placed by pilgrims between a rally and a temporary life on the road, but the social structure at Szpakowisko and in pilgrimages was different. Generally, the differences can be found in the moral-spiritual and religious spheres.

12 Notes made available by Fr Szpak, own collection.

13 The participants were usually in their teens or early twenties, more rarely between twenty and thirty or older.

14 After Fr Szpak's death, the people involved in Szpakowisko and other of his initiatives organised successive Szpak pilgrimages in 2018 and 2019 which are a continuation of his work. 
Since the very beginning, the Szpak rallies had been a space open to everybody ${ }^{15}$. There were no participation criteria, admission rules, character typologies according to which some people were more welcome than others. However, in this last case we can talk about some worldview-related and mental similarity. The common denominator for the majority of the participants of Szpakowisko was an unfulfilled need for affiliation and a search for their own way of life. There were not attendance lists there, so today nobody can say how many people participated in those meetings during almost thirty years.

In the 1980s, Szpakowisko had a label of a pathological group ${ }^{16}$. They comprised normative youths that identified themselves with the hippie movement, the punk or metal subcultures, environmentalists, addicts, and people who had served time in prisons. The reports of priests who hosted the 'Szpak youth' in their parishes included information about non-normativeness. It was emphasised that a "few intoxicated people" were found among the few dozen participants, and one person was removed for improper behaviour. Provocations were observed, such as during the rally in Krasiczyn where "pacifist symbols were painted in blue on official buildings, a kiosk, kindergarten, and vulgar words in two cases"17. For that reason most of the rally participants, the priest included, were interviewed by the Citizens' Militia (police) "who were concerned about the coincidence between the rally and the VIII Party Congress". In those times the participants of Szpakowisko were treated as a group of misfits from whom rebels against the communist power were recruited. In reality, those were young people searching for another man, master, pattern or ideal ${ }^{18}$.

The shape of Szpakowisko gradually changed after 1989. The new generation, relatively divided and coming from different milieus, started to form a group even more varied in terms of age, character, interests, involvement, values and 'subcultural' preferences. Already earlier, the punks, alcoholics or drug addicts were a contrast to the colourful hippie-like individuals, but all tolerated each other and were eager to converse with other people. Disturbed or mentally ill people were also a sort of folklore - they were treated with understanding, although in a slightly patronising manner. Using the pedagogical terminology, it can be said that Szpakowisko in 1990s was a support group or an integration group. The mentally disturbed found respect and understanding, and the healthy learned coexistence and acceptance of behaviours unknown till then. The 'normal' had a chance to observe the symptoms and effects of addiction, sporadically appearing punks could learn positive and pro-environmental thinking, pot smokers

15 Szpak, Idź Mojżeszu..., 48-53.

16 https://ninateka.pl/film/byc-czlowiekiem-julian-pakula (access: 24.06.2020).

17 A document of the Parish Office in Krasiczyn of 15.02.1980 sent to the Diocesan Curia in Przemyśl (own collection).

18 Statement of Fr Andrzej Szpak in the film "Być człowiekiem", directed by Julian Pakuła, 1983. 
could discuss with teetotallers, and alcoholics, if they were sober, could talk to alcoholics' children. Pedagogists discussed with physicists, and reggae lovers with blues afficionados. Such mutual education was not controlled by Fr Szpak who was more of a companion than a teacher. In his homilies he underscored the importance of mutual respect, openness and love of onee oneighbour, regardless of who they are and how they participate in reality. The discussions during Szpakowisko oscillated around the limits of acceptance, tolerance, independence, expressing one's views or making decisions. Many learned how to respect a person regardless of whether they are intoxicated at a given moment, are mentally ill or have low self-esteem.

Not only people involved in the organisation of rallies participated in Szpakowisko, there were also 'long-term observers' who came only to be among the people similar to them, who do not impose anything upon them. Kids from normal families whose positively thinking parents accepted the trips, and children of alcoholics from broken families, who at home experienced either an extreme laissez-faire or an aggressive despotism ${ }^{19}$.

The support group operated as a community whose members had similar problems, life stories, had a direct contact with each other, met and helped each other, learnt from each other, and it was a necessary social structure particularly for those who did not feel understood in their families or local communities. Support groups are especially important for young people with an unfulfilled need for affiliation, association and support in some social reality. Taking these factors into account, Szpakowisko can be described with four elements building group support: a common communication code, common searching, group mentality and (self)exclusion community. However, before they are described, it is important to indicate the context and emphasise the importance of identity building not only for an excluded person, but most of all for a self-excluded person ${ }^{20}$.

\section{Building the Group Identity}

Cultural stimuli of the last decades, such as psychoanalysis, structuralism, negative thought, neo-nihilism or cybertheories, urge us to reaffirm human subjectivity which forms in the individual's identity. The term 'identity' most often appears in philosophy and psychology and in resocialisation pedagogics, particularly in the creative resocialisation concept ${ }^{21}$. In the philosophical sense, it is a relation between each object and itself, which means that each object is identical with itself. In

19 Kmiecik-Jusięga, Szpaku..., 202-208.

20 Self-exclusion can be a result of social exclusion, but also of individuals' placing themselves outside social systems, without previous stigmatising incidents and previous labelling.

${ }^{21}$ See Marek Konopczyński, Metody twórczej resocjalizacji (Warszawa: PWN, 2015). 
psychology it appears also in a relation - it is a relation between an individual and himself or with another individual, most often in the context of culture and tradition $^{22}$. Etymologically the identity is being the same, sameness, identification with oneself. There are concepts of identity definition which describe the identity as:

- sense of one's identity, that is the self-knowledge system;

- property of a 'pure ego';

- component of the term 'I', self-knowledge;

- symptom, structure of 'I' as an element of being different from other people;

- symptom of one's exceptionality in the context of culture and tradition.

On the other hand, the most frequently listed identity criteria include: sense of being different from the surroundings, sense of continuity of a person's self, and sense of internal cohesion and content. Although the psychologists differentiate between the sense of identity and the identity itself, the identity is very often defined as the sense of being someone who, despite changing external conditions, circumstances, events and relations with other people, maintains continuity and cohesion in their image of themselves.

If such continuity and cohesion is disturbed, we can talk about identity crises, typical for the period of adolescence and young adulthood ${ }^{23}$. All people at different moments of their lives determine whether what they know and think of themselves and how they are perceived by others fits with their own image. If the discrepancies are huge, there is not only a cognitive dissonance that is an unpleasant tension that results from the incompatibility of opinions, but also bad emotions and thoughts about oneself. For we are inclined to assign to ourselves the qualities that others see in us, particularly important others, and not the qualities which we see in ourselves. This is the reason why relations with other people are so important and the search for authorities who help us organise the world and our self-image in the social reality. Fr Andrzej Szpak was such an authority, who listened to young people and showed them their virtues, helped organise difficult situations and explained behaviours by referring them to religious articles of faith.

The group identity, being a form of social identity, is described in the literature as a set of beliefs and self-definitions with which we describe ourselves in the community of other people. We assign membership to ourselves, we observe certain norms and rules, we adapt to some formal and informal requirements. The group identity can be prosocial if the group we belong to meets the pro-society requirements, acts for the benefit of an individual, gives rewards which an individual takes advantage of also outside the group, but it can also be antisocial

22 See Krzysztof Krzyżewski, Anna Kazberuk, "Specyfika psychologicznego ujmowania tożsamości”. In: Tożsamość człowieka, ed. Anna Gałdowa (Kraków: Wydawnictwo Uniwersytetu Jagiellońskiego, 2000).

${ }_{23}$ Term by Erik Erikson who formulated the theory of identity crises in the life cycle and described each development phase of an individual as a moment of crisis. 
when the group is deviant, amoral, destroying, criminal (in terms of violating the legal norms), when all an individual receives from the group is mainly negative behaviours and beliefs and losses.

The building of group identity is often a process which is on the one hand long and requires effort, calculations and specifying yourself inside the group, and also yourself as a subject for whom the group is a background defining the 'self' and describing the space of thoughts, behaviours, attitudes, beliefs and situations that comprise the entirety of the perceived fragments of the world. On the other hand, particularly in case of a teenager or a twenty-year-old, the identity building can 'happen' momentarily, when the person understands or believes he/she understands who they are 'here and now', without a reference to a longer future or past perspective. The 'day identity' or fluid 'fast' identity, widely reconstructed by Zbyszko Melosik, is typical not only of $21^{\text {st }}$ century youth ${ }^{24}$; it was also a feature of the youth in at least a few decades of the $20^{\text {th }}$ century. Szpakowisko was frequented by people who functioned within the so-called youth subcultures (mainly hippies and punks) or identified only with the 'Szpak's group. This was a certain indicator, showing the affiliation and specific mentality of the 'Szpak's people'.

According to Irena Pospiszyl, there is an inverse relationship between the personal identity and the social identity, meaning that when a person focuses on the personal identity, their interest in the group identity wanes, whereas when they focus on the group identity, their personal identity disperses. This can explain the behaviours of some Szpakowisko participants who called themselves hippies, cared only and exclusively about 'being hip', and not about finding their own definition of themselves. On the other hand, and in the vast majority of cases, one does not exclude the other, which contradicts the Pospiszyl's thesis that by assuming the group identity, maladjusted individuals mask and compensate for the underdeveloped personal identity, and the group identification can be a barrier in developing the personal identity ${ }^{25}$. The conclusion is that the participants of rallies organised by Fr Szpak were by all means the adapted group because by assuming the group identity, they shaped their own personal identities. Moreover, by growing attached to the group they cared about the emotional, intellectual, spiritual and social self-development. This was confirmed by Fr Szpak who wrote that "the purpose of Szpakowisko is to work on yourself, prayer, self-reliance, coping with difficulties, self-improvement,

${ }^{24}$ Zbyszko Melosik, "Rekonstrukcje tożsamości życia młodzieży współczesnej. Próba diagnozy i pedagogicznej propozycji”. In: Młodzież między ochrona a ryzykiem. Wspieranie rozwoju oraz pomoc psychologiczno-pedagogiczna dla adolescentów i adolescentek, ds. Barbara Jankowiak, Agata Matysiak-Błaszczyk (Poznań: Wydawnictwo Naukowe UAM, 2017), 19-48.

${ }^{25}$ Irena Pospiszyl, "Identyfikacja z grupą jako sposób rozwiązywania problemów własnej tożsamości”. In: Tożsamość grupowa dewiantów a ich reintegracja społeczna, eds. Wiesław Ambrozik, Anna Kieszkowska (Kraków: Oficyna Wydawnicza "Impuls", 2012), 53-54. 
self-education, autocreation, self-portrait, autobiography, auto-evangelisation, autonomy, development of one's potential, talents, predispositions, properties, virtues $[\ldots]]^{\prime 26}$.

\section{Common Communication Code: Pseudonyms and Emotions}

Despite an unusual (for a single group) diversity of external appearance and communication, the language and the values were more uniform. The use of pseudonyms was typical - these were sometimes formed from names, surnames, but also derived from interests, appearance or behaviour. Sometimes the pseudonyms were not related to the above. The people participating in Szpakowisko who had known each other for many years, could know only their nicknames, not being interested in what the person's real name was, how old were they, where they lived, who their parents were etc. This was an internal communication code, known only to the chosen ones. The peculiar elitist character of the group undoubtedly contributed to the fact that the group was treated as reference in building one's 'self'. What was the reason for the need to use nicknames? Certainly, one reason was the use of a new identity at Szpakowisko where non-normative behaviours were fully accepted. A young man or woman who was not accepted (e.g. by the family), reprimanded for their aversion to work or education, at Szpakowisko could show their musical skills or tastes to activities other than those preferred by their parents or teachers. An example could be an eighteen-year-old man who could make complicated needlework for which he was rejected by his father.

The emotional dimension of communication at Szpakowisko was a free expression of what one was feeling at the moment, without external masks, but also without reference to social coexistence rules which could be qualified as so-called inner values described in Gresham Sykes's and David Matza's neutralisation theory. Speaking freely that you are sad or cheerful, mad or happy, irritated or calm. It is also a full acceptance by the vast majority of participants of emotional behaviour such as hugs, throwing into arms of others, unexpected cries of joy or anger, bursting into tears and the like. Absence of boundaries in this 'freedom', going to extremes, effusiveness, emotionality and excessive exaltation were frequent during Szpakowisko and were a sort of emotional catharsis.

A code is usually defined as a system of symbols which form a whole that has a meaning and a certain content. The very fact of membership in a group which has a specific communication code makes a young man or woman less lonely; such a person starts to make their own history, particularly when they dissociate

26 Notes made available by Fr Szpak, 1992, own collection. 
themselves from their own family or environmental narratives. Due to ties between Szpakowisko and hippie rallies, there are also codes related to the symbolism of the world hippie movement in late 1960s and early 1970s. These were specific elements of dress, ornaments or haircuts used as a basis to establish relations ${ }^{27}$.

\section{Searching and Mentality of Szpakowiska}

The contradictions in expressing one's beliefs or emotional states are frequently caused by the lack of a structuralised system of values and by searching for one's way which any man searches for as long as they need it. Some find it in the paths of their parents, some search in distant lands or cultures and never find it. But such a search in Fr Szpak's group was very specific. Searching for love, ways to understand freedom was a tangent point for many participants of Szpakowisko, which was natural in a group comprising mainly young people who just form the image of themselves.

Despite different worldviews, it can be assumed that there was a group mentality of people gathered around Fr Szpak; it was based on a specific sensitivity and acceptance of even the most bizarre behaviours, appearance or beliefs. Only aggressive behaviour and sexual pathologies were not tolerated. A similar mentality expressed itself in mutual trust and attitudes towards the behaviour of other people. The mentality was also the community of values, such as inter alia freedom, peace, good, beauty, truth. Values are a foundation for each human community, particularly for young people who are looking for their place in personal worlds. Thus, we can talk about the Szpakowisko mentality whose characteristic traits, in addition to the aforementioned, included acceptance of otherness, distinctness, abstract thinking and inadequate behaviour.

\section{Self-exclusion Community}

Social exclusion is an ambiguous and vague term indicating various phenomena that affect people in a certain sphere, to a certain degree and in a certain context different from the statistical majority. To ponder what the exclusion is, one has to answer the question what is a norm and what laws it establishes to exclude the individuals who do not fit the norm.

The norm is most often perceived as a synonym of conforming to the socio-cultural expectations of the majority. This is a statistical-psychometric definition, where the normality criterion is established by people who are in the demographical advantage. The norm can also be defined in a cultural way where the

\footnotetext{
${ }^{27}$ More on this code in: Kmiecik-Jusięga, Szpaku...
} 
normality criterion is established by 'dominating others', and also cultural patterns, values and standards developed for a longer time. The norm can also have a psychiatric, pedagogical and psychological character where the normality criterion is the feeling of good functioning, level of satisfaction, mature personality, education, etc. The last way to define the norm is the ethical-religious method, according to which the norms were established for millennia by decision-makers and creators of religious-ethical laws ${ }^{28}$. Failure to abide by the established criteria causes the rejection by those who adhere to them. But on the other hand, the maladjustment can be very conscious and intentional, resulting from the lack of willingness and purpose to adjust. "I do not go to school because the teachers do not respect me or abuse me emotionally". "I do not form relationships in my local community because this community stigmatises me". "I don't get a job suggested by my parents because I feel I'm losing time and my interests are quite different and nobody has asked me about them". These are strong arguments for maladjustment to social norms, and the exclusion as a result.

A great deal of myths and inaccuracies have appeared over the years around social exclusion, resulting most likely from the lack of a systemic approach to the issue and the attempts to pass judgements on it ${ }^{29}$. The exclusion can be thus characterised as way of communicating the 'abnormality' to the marginalised individuals $^{30}$, as a social phenomenon or situation affecting chosen ethnic, national, cultural, sexual, criminogenic minorities, or as a term that facilitates the establishment and application of laws. We can also speak about different dimensions of social exclusion. Julien Damon lists four: consumption (net income per unit of consumption below half of the average, an inability to buy certain products, no creditworthiness); production (unemployment, occupational disability, poor education, premature retirement); social involvement (no affiliation with formal groups such as associations, social or political organisations, lack of interest in politics); and social interactions (lack of close people who can give emotional and spiritual support, impossibility to form social relationships) ${ }^{31}$. One can also add a criminological dimension (committing crimes, participation in criminal

28 Classification of norm definitions according to Ewa Wysocka, Diagnoza $w$ resocjalizacji (Warszawa: PWN, 2008), 21.

${ }_{29}$ The terms 'social exclusion' and 'social maladjustment' are most often used in the literature on special pedagogics, social work, penitentiary studies and economy. The term 'exclusion' was interdisciplinarily analysed by Małgorzata Michel, "Gra w wykluczenie społeczne w świecie płynnej rzeczywistości”. In: Tożsamość grupowa dewiantów a ich reintegracja społeczna, part II, eds. Wiesław Ambrozik, Anna Kieszkowska (Kraków: Oficyna Wydawnicza "Impuls", 2012).

30 The indicators of marginalisation leading to exclusion have many individual, social, economic, geographical, etc. conditions. See: Maria Chodkowska, "Pedagogika wobec wyzwań przeciwdziałania marginalizacji i wykluczeniu”. In: Pedagogika wobec zagrożeń marginalizacja jednostek, grup i regionów, eds. Maria Chodkowska, Aleksandra Mach (Rzeszów: Wydawnictwo Uniwersytetu Rzeszowskiego, 2011).

31 Julien Damon, Wykluczenie (Warszawa: Oficyna Naukowa, 2012), 35. 
groups, no observance of penal law), a cultural dimension (no involvement in cultural life, inability to use cultural goods), an educational dimension (lack of education, lack of access to information, lack of knowledge about basic issues pertaining to the surrounding reality), and a religious dimension (no involvement in religion, no participation in rituals).

Self-exclusion is, however, characteristic for many participants of Szpakowisko. The excluded often exhibit traits of learned helplessness, they do not understand the problem they are in, they are not aware of their life situation, are not motivated to change the situation, do not draw conclusion, are unable to learn from their mistakes. On the other hand, those who have excluded themselves from social life for the aforementioned reasons are usually aware of their situation and do very well in it. They can draw conclusions and learn from their mistakes, but are not willing to adapt to the structures in which the majority functions. It is their choice, for which, whether they like it or not, they bear all consequences.

\section{Conclusion}

The aforementioned fragmentations of the historical social movement and the described elements building the group support in Szpakowisko are not a full description of the phenomenon which was a hard-to-define mosaic of people in search of their 'self', but also self-excluded from their environments, often creative, independent-minded, but also lost, lonely and sometimes addicted.

In the perspective of many meetings and relations established during Szpakowisko, I venture to suggest that Szpakowisko was a sort of alternative for therapeutic support groups and the area of self-realisation in the situation of social exclusion, most often for personality reasons. In the $21^{\text {st }}$ century, an example of a grassroots youth movement, including peer leaders social projects or independent youth voluntary groups, can be a remedy for civilization disorders and diseases such as addiction to the Internet, computer games and social media where young people form indirect and superficial relations.

This peculiar community led by Fr Szpak - often judged by outside observers or scholars as a pathogenic group of rebellious youths - has generated not only self-reliant and educated people but also people of great faith who help others with their wisdom and experience, such as a psychologist and personal development coach, the author of a very touching publication Wyjrzeć przez okno [Look Out the Window], Anna Kulka-Dolecka who says that:

[...] people who did not know Andrzej Szpak, probably mainly journalists, call him a hippie priest, drug addicts minister or troubled youth preacher. Perhaps these terms are to some extent true, but I object - they tag this extraordinary man and really do not say anything about him... Because he is our Szpaku, ours - the 'Szpak's people'. 
He is a guardian and a guide for ANYBODY who was seduced by and addicted to his view of the world, love of nature, admiration of the smallest blade of grass or flower, his childish-mystical spirituality, wild heart, courage to go beyond the patterns, gift to unite people and win hearts. I never was a drug addict and was a rather easy and nice young person. And what I am now and my attitude towards what happens in my life, I owe largely to him $^{32}$.

\section{Szpakowisko. Rzecz o młodzieżowym ruchu, który wspierał budowanie tożsamości grupowej osób (samo)wykluczonych}

Streszczen i e: Celem artykułu jest przybliżenie mało znanego zjawiska społecznego, tworzonego przez młodzież, która od lat 80 . XX wieku do pierwszej dekady XXI wieku uczestniczyła w Szpakowiskach, czyli cyklicznych spotkaniach, nad którymi pieczę sprawował ks. Andrzej Szpak, salezjanin (1944-2017). Naświetlone zostaną specyficzne dla Szpakowisk czynniki, które przyczyniły się do zsocjalizowania osób pierwotnie wykluczonych albo samowykluczających się ze struktur społecznych. Autorka próbuje odpowiedzieć na pytania: czym charakteryzował się ruch młodzieżowy zwany Szpakowiskiem? Które elementy tego ruchu można opisać w charakterze czynników budujących tożsamość grupową? We wprowadzeniu została przedstawiona metoda badawcza oraz dylematy związane $\mathrm{z}$ tematem artykułu. Następnie scharakteryzowano Szpakowisko jako grupę wsparcia, omówiono proces budowania tożsamości oraz wyróżniono wybrane elementy omawianego zjawiska, takie jak: wspólny kod porozumiewania się, poszukiwania, mentalność i wspólnota samowykluczenia.

Sło w a klu c z ow e: Szpakowisko, ruch młodzieżowy, tożsamość grupowa, samowykluczenie

\section{References}

Bomba, Jacek. “W poszukiwaniu tożsamości”. In: O dorastaniu, czyli kod buntu, ed. Piotr Legutko. Kraków: Wydawnictwo Literackie, 2002.

Chodkowska, Maria. "Pedagogika wobec wyzwań przeciwdziałania marginalizacji i wykluczeniu". In: Pedagogika wobec zagrożeń marginalizacja jednostek, grup i regionów, eds. Maria Chodkowska, Aleksandra Mach. Rzeszów: Wydawnictwo Uniwersytetu Rzeszowskiego, 2011.

Damon, Julien. Wykluczenie. Warszawa: Oficyna Naukowa, 2012.

Kmiecik-Jusięga, Karolina. "Festiwal Sacrosong w dokumentach Służby Bezpieczeństwa w latach 1974-1980”. In: Stań się. Święto Boga Ojca Stworzyciela. Nowa misja Sacrosongu. Zbiór referatów z sympozjów naukowo-artystycznych 2013-2015, eds. Andrzej Szpak SDB, Małgorzata Pelc. Kraków: Poligrafia Salezjańska, 2016.

Kmiecik-Jusięga, Karolina. "Ksiądz Andrzej Szpak SDB - duszpasterz niedostosowanych”. Remedium 2 (2013).

Kmiecik-Jusięga, Karolina. Szpaku. Metody pracy księdza Andrzeja Szpaka z młodzieżą różnych dróg. Kraków: WAM, 2013.

Konopczyński, Marek. Metody twórczej resocjalizacji. Warszawa: PWN, 2015.

32 www.doziemiobiecanej.pl (access: 20.01.2020). 
Krzyżewski, Krzysztof, Kazberuk, Anna. "Specyfika psychologicznego ujmowania tożsamości”. In: Tożsamość człowieka, ed. Anna Gałdowa. Kraków: Wydawnictwo Uniwersytetu Jagiellońskiego, 2000.

Melosik, Zbyszko. "Rekonstrukcje tożsamości życia młodzieży współczesnej. Próba diagnozy i pedagogicznej propozycji”. In: Młodzież między ochrona a ryzykiem. Wspieranie rozwoju oraz pomoc psychologiczno-pedagogiczna dla adolescentów i adolescentek, eds. Barbara Jankowiak, Agata Matysiak-Błaszczyk. Poznań: Wydawnictwo Naukowe UAM, 2017.

Michel, Małgorzata. "Gra w wykluczenie społeczne w świecie płynnej rzeczywistości”. In: Tożsamość grupowa dewiantów a ich reintegracja społeczna, eds. Wiesław Ambrozik, Anna Kieszkowska, Kraków: Oficyna Wydawnicza „Impuls”, 2012.

Nanni, Carlo "Personalistyczny wymiar filozofii wychowania". In: Personalistyczny wymiar wychowania, eds. Anna Szudry, Katarzyna Uzar. Lublin: Wydawnictwo KUL, 2009, 69.

Nowak-Dziemianowicz, Mirosława. Walka o uznanie w narracjach. Jednostka i wspólnota w procesie poszukiwania tożsamości. Wrocław: DSW, 2016.

Ojciec, ed. Sławomir Jabłoński. Poznań: Wydawnictwo Fundacji Humaniora, 2000.

Pospiszyl, Irena. "Identyfikacja z grupą jako sposób rozwiązywania problemów własnej tożsamości”. In: Tożsamość grupowa dewiantów a ich reintegracja społeczna, eds. Wiesław Ambrozik, Anna Kieszkowska. Kraków: Oficyna Wydawnicza "Impuls", 2012.

Szpak, Andrzej SDB. Idź Mojżeszu. O pielgrzymce, hipisach i ziemi obiecanej. Kraków: ESPE, 2015.

Szpak, Andrzej SDB. "Wychowanie religijne w ruchu hipisów i młodzieży różnych dróg. 40-letnie poszukiwania i doświadczenia duszpasterskie”. In: Hipisi, wędrowcy marzeń i poszukiwacze wolności na ścieżkach wspótczesnej kultury, eds. Gerard Guźlak, Anna Pietrzak. Bydgoszcz: UKW, 2016.

Urbaniak-Zając, Danuta, Kos, Ewa. Badania jakościowe w pedagogice. Wywiad narracyjny i obiektywna hermeneutyka. Warszawa: PWN, 2013.

Wysocka, Ewa. Diagnoza w resocjalizacji. Warszawa: PWN, 2008.

In addition, the following audio-visual and internet sources were used:

Extended interview with Fr Andrzej Szpak by Gabriela Mruszczak, Filmoteka Małopolska, produced by RAMstudio Company S.C., https://www.youtube.com/watch?v=gJs2bjc08To (access: 28.01.2020).

Video from Fr Andrzej Szpak's book reading organised at Ignatianum University in Kraków on 27.11.2015 (promotion of “Idź Mojżeszu” book). Author’s private archives.

Facebook pages dedicated to the Various Roads Youth Pilgrimage.

Film "Być człowiekiem”, directed by Julian Pakuła, Wytwórnia Filmów Dokumentalnych, 1983, https://ninateka.pl/film/byc-czlowiekiem-julian-pakula (access: 24.06.2020).

www.doziemiobiecanej.pl (access: 20.01.2020.) 